DOI: $10.20472 / T E .2017 .5 .2 .004$

\title{
IMPLEMENTATION OF "ACTIVITY THEORY" IN THE FRAMEWORK OF DIFFERENTIATED TEACHING: A CASE STUDY
}

\author{
POLYXENI MITSI, GEORGIA PAPASPYROU
}

\begin{abstract}
:
In the present paper the exploitation of an alternative teaching capability, that of "The activity theory" which can be implemented during differentiated teaching is examined. More specifically, differentiated teaching aims at students' activation, their substantial participation during teaching in order to better acquire knowledge. To this end, the experience of each student is considered significant thus each one of them approaches knowledge in different ways through cognitive knowledge and socio- emotional change. From this perspective, the aim of this paper is to present the effectiveness of practical implementation of "Activity Theory" in the framework of Differentiated Teaching as a tool to change basic meanings of the learning environment. In order to investigate qualitatively the didactic implementation of "Activity Theory" during differentiated instruction in the educational process, we present a case study in the sixth grade of a Greek elementary school. We used the experimental method of research and the research results emerged by a structured questionnaire for the cognitive level, the participation and cooperation demonstrated by the students during the instructional scenario. The results were compared with those emerged at the same class in a different object of teaching-learning in which the students had not received the implementation of "Activity Theory" during differentiated instruction. The main conclusion showed that the practical implementation of "Activity Theory" in the framework of Differentiated Teaching maximized the students' academic achievements and highlighted the potential of using the combination of alternative teaching methods as a mean for students' activation and substantial participation during teaching.
\end{abstract}

\section{Keywords:}

activity theory, differentiated teaching, instructional scenario

JEL Classification: 129

\section{Authors:}

POLYXENI MITSI, University of Ioannina, Greece, Greece, Email: pollymitsi@yahoo.gr GEORGIA PAPASPYROU, University of Patras, Greece, Email: gpapaspi@upatras.gr

\section{Citation:}

POLYXENI MITSI, GEORGIA PAPASPYROU (2017). Implementation of "Activity Theory" in the framework of Differentiated Teaching: A Case Study . International Journal of Teaching and Education, Vol. V(2), pp. 57-73., 10.20472/TE.2017.5.2.004 


\section{Introduction}

The social and cultural pluralism of modern reality has demonstrated more than ever in the field of learning and especially teaching, the distinction of what the student already knows and experiences refuting thus the notion of the "average means" of students (Tomlinson, 2010). On the other hand, there are elements of a standardized type of teaching which are proven to be insufficient for all school needs (Koutselini \& Persianis, 2001). Towards this effort differentiated teaching constitutes a significant method since it is oriented on how well -prepared each student is, his interests, his learning profile and aims at ensuring that all students will actively participate during teaching, they will feel safe and ready to acquire new knowledge (Reis et al., 2011). The aim of this paper is to investigate how students acquire cognitive and social knowledge based both on their individual learning profile, needs-interests and the instructional flexibility that differentiated teaching provide.

\section{Setting boundaries in differentiated theory}

Differentiated teaching is the adaptation of teaching to the individual needs of each student (Tomlinson, 2004). In other words, differentiated instruction is a means of teaching to all students of mixed abilities in order to help them reach the common goal, the maximization of academic achievements even if they follow different learning paths (Robinson et al., 2014). It is performed through alternative teaching methods in order to be in tune-with the demands of the students and based on their learning profiles (Tomlinson, 2010:27-28). These methods require flexibility of the teaching hours, analytical presentation of the teaching subject (Matsagouras, 2008), determined targets regarding teaching and evaluation of teaching (Joseph et al., 2013 Koutselini \& Patsalidou, 2015).

One could say that differentiated teaching is more a way of thinking than a strategy or a target someone must achieve and it is mainly used by teachers in order to organize their teaching methods (Theofilidis, 2009, Tomlinson, 2010).

For the implementation of differentiated teaching there is not a particular process one must follow, although there are some principles that characterize it. Teachers focus primarily on the basic parts of their teaching object that strike the interest of the students and transfer significant knowledge (they are important). All students actively participate during learning encouraging thus the notion of collaboration, individual and team work (Kanakis, 2001). Additionally, flexible learning and teaching strategies are present (Tomlinson, 2010).

The term "differentiated" does not necessarily mean that each student has a different learning and teaching approach. Everything is based on flexible design and evaluation takes the form of feedback/assessment (Karageorgou, 2008).

For the design of differentiated teaching the steps that teachers should follow are: 


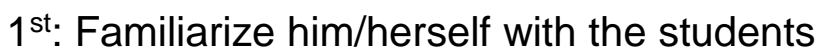

$2^{\text {nd: }}$ Consider various teaching strategies

$3^{\text {rd: }}$ : Choose teaching activities

$4^{\text {th: }}$ : Select evaluation methods (Argiropoulos, 2011).

In the process of differentiated teaching more so than in traditional teaching, fundamental principles such as the students' needs, learning profile, talents, potential, capabilities as well as their socio-cultural background should be considered (Hall, 2002, Tomlinson, 2010). The method's basic aim is the activation of students' attention, the provision of stimuli, the usage of the existing knowledge, the exploitation of alternative coding methods, feedback (Flouris, 2005), the encouragement of communication and self evaluation/self efficacy (Panteliadiou \& Filippatou, 2013·Valiandes \& Neophytou, 2017).

It is also important to take into account the following parameters: a) the consistency in the flow of teaching hours, b) the use of multiple teaching materials for each subject and c) the creation and constant updating of an evaluation portfolio for each student. No comparison must be made among students (Tomlinson, 2014 -2010).

The educational system fills classrooms with a great amount of about 25 students of the same age and has the expectation that have the ability and the tools to comprehend the same presented information in the same way (Robinson et al., 2014). Rarely two individuals in the same age and class learn in the same way and follow the same timetable. The reality in education and especially in each classroom is that students differentiate in the way they acquire the information and the methods they use for it (Tomlinson, 2009). Besides, Gardner (1983) first identified the variety of intelligences that are relatively independent but interacting cognitive capacities. Each student doesn't demonstrate a unique set of intellectual strengths and weaknesses in one area (Bender, 2012). Consequently, scaffolding work, interesting and innovating lessons and creation of more opportunities for all students is required (Morgan, 2014). Differentiated teaching requires a small number of students in each class in order to have more freedom as well as adequate parents' consent concerning this method and its benefits in the overall learning process (Tomlinson, 2010).

Differentiated teaching is closely related to and based on teachers and their teaching flexibility (Joseph et al., 2013). Differentiated teaching it is not a priori a conventional method of teaching but more based on active participation in the process of learning and focuses basically on research (Panteliadou \& Filippatou, 2013). The effective implementation of differentiated teaching in practice discards the traditional, conventional and easy way of thinking and teaching, while demands enough effort, dedication and patience (Valiandes \& Koutselini, 2008). Research findings showed that teachers perceive successfully the implementation of differentiated teaching even though they recognize basic obstacles that need time and effort to overcome them. Teachers decline the need for more direct professional development 
opportunities for differentiated instruction which addresses classroom management, supporting material, implementation contents and strategies that have been proven to be effective in classrooms across the curriculum (Robinson et al., 2014). Teacher education institutions may transform their programs to reflect the realities of the $21^{\text {st }}$ century educational system (Chesley \& Jordan, 2012).

Students, through differentiated teaching, reach their own reality/results by being objective leading themselves to their own conclusions. This all happens by using their emotions and their participation in the whole process, using the recently acquired knowledge and combining it with data processing (Panteliadiou \& Filippatou, 2013 Valiandes \& Neophytou, 2017). The implementation of differentiated teaching and the changes it promotes make students' attitudes more positive towards learning and may generate a better and more productive learning environment (Cha \& Ann, 2014).

All in all, differentiated teaching contributes to the avoidance of student failure (Kim, 2005). Students participating in teaching become more autonomous (Craib, 1998). It is also a means to eliminate any inequalities that appear among students providing them with different but equal opportunities (Panteliadou \& Filippatou, 2013). They feel they are responsible for the knowledge they gain rather than controlled and evaluated. Teachers on the other can better monitor their students' progress, to provide them with help by offering them the appropriate guidance (Craib, 2011). Also, teachers provide students with adequate scaffolding and support, as well as opportunities for peer and self-evaluation (Joseph et al., 2013·Santangelo \& Tomlinson, 2009).

To this end, it seems that differentiated instruction may have positive results in the context of continuously increasing social changes and demands as far as it provides effective alternative teaching methods, which leads to the diversity of today's educational population.

\section{Structural characteristics of activity theory in the framework of differentiated teaching}

\section{Theoretical approach of Activity Theory}

The term "differentiation" is based on the theory of Constructivism which supports the view that learning is a process of personal issues that depend on previous knowledge and sentimental schemes of each student as well as their activities' form, changes and/or their enrichment through social interaction (Piaget, 1964).

Activity Theory provides the theoretical background of understanding and studying human behavior and how experience and knowledge, as fundamental parts of the teaching activity, mediate and interact between students and their environment making them aware of it (Taylor, 2014).

Based on the above, learning entails social, historical and cultural characteristics that influence the students' performance on two levels: the social one that involves a 
person's relationships with the cultural elements and the psychological that involves how a person perceives and changes his intellectual functions (Vygotsky, 1981, Koliadis, 2007).

Activity Theory recognizes two main functions:

a) Internalization, which is closely related to the reproduction of knowledge and particularly to the training and socialization of students during the process of an activity and

b) Externalization which is considered the carrier of new instruments that transform the wider culture and models of the activities through the use of distinctive innovations and provision of strategic solutions (Engeström \& Miettinem, 2003, Stamoulis \& Plakitsi, 2011).

Activity Theory has been described as a flexible and developing social-cultural theory that regards learning as the result of social participation and interaction, describing how each student, through his participation in social communities, gains new knowledge, shares common objects and is regarded as a complete member of his school class (Campell, et al, 2014). Learning possesses a holistic characteristic that not only enables the limits between the learner, the community and the wider social environment, but also promotes a) the active participation of individuals (students), b) the conquest of learning and transformation, c) the recognition of the student as a complete and peer member of the community capable to use his knowledge widely, in the framework of alike future situations (Koliadis, 2007).

According to Vygotsky (1978), an activity orientated towards the objects, that mediate through the cultural tools and signs, entails the goals and the results set by humans and by fulfilling the activity, people change and develop themselves.

Further, based on what Leont'ev and Luria (1978) claim emphasis should be placed more on collective activity. Engeström (1987) on the other hand focuses on interaction activity systems (Stamouli, Plakitis, 2011).

\section{Structure of Activity Theory}

Learning is a human activity which is primary socially oriented. "Activity Theory" holds the view that the knowledge of previous generations depicted in the form of objects, values, norms and various cultural sights mediate in the social interactions of the individual with the world (Campell, et all, 2014), resulting in alteration and reproduction of living conditions. Within this framework, the Activity Theory examines the history, the job allocation and the cultural norms of the intervening parts.

Based on the above, the term activity entails a specific social characteristic of humans that aims at purposeful alterations of its direct and indirect environment- in this case the student's. These alterations should be achieved through transformations of the 
student's initial beliefs regarding the world. Basically, it is an internal change in the way of thinking and action of the person (Davydov, 2003).

As a result, the activity activates and promotes the acquisition of knowledge and of skills in new situations, in the problematics that arise as result of conquered knowledge, in the comprehension and re-assessment of the object's significance and structure, in the alternative way of action and the use or rejection of stereotypes (Ntmitrief \& Stepanof, 1989).

For Vygotsky (1978), activity is a material, practical, social and collaborative process that aims at changing the world and constitutes the base of human life and its relationship with the world.

On the other hand, "mediation" is the mechanism through which social and cultural activities are formed into internal intellectual functions (Stamouli, Plakitis, 2011). Sources of this kind of mediation can be material tools, symbolic systems or other behaviors.

The use of tools and signs in the acquisition of knowledge (objects) according to Koliadis (2007) enables people a) to develop and form higher level behaviors and b) use their knowledge for future similar situations. In this way, the activity that is oriented towards a specific object is rather the outcome of a motive.

Leont'ev $(1978,156)$, claims that motives are products of "individuals' intentions" and they are a complex psychological process that depicts human needs as they form when people interact with their environment. As a result, the activity entails particular targets and is influenced by a motive that represents the relationship of people with their environments and their desire to approach particular objects (Engeström, 2003, Park, 2015).

Engeström (1999) enriches the Activity Theory by introducing the model of system analysis of the activities. This includes the defining of social and material sources as well as the collective motives that interact with people or various social groups in order to make the "objects" visible and ready to be achieved (Engeström, 2003:167).

The basic elements that formulate an activity system are: the subjects, the objects, the mediated tools, the rules, the communities and the division of labor.

Subjects are the individuals or groups of individuals that share the mediating tools activity. Objects are the motives that are hidden in the subject's participation in the activity. The subject and the object interact and both characterize the human activity which takes form and shape from the dynamic influence of the motive (Engeström, 2003, Park, 2015). Furthermore, learning and conscious activity are interrelating and interdependent processes (Zhang, 2014, Taylor, 2014). The object is the outcome of the collective action and an element of the cultural, social and historical environment within which people familiarize themselves with the objects and modify both their environment and themselves (Matsagouras, 1998, Campbell et al, 2014). The mediating tools are symbols, signs and conceptual understanding and function as 
physical and psychological tools that mediate between the subject and the object (Campbell et all, 2014). The community is the social and cultural group in which the subject lives. It is structured by rules and social norms that coordinate and influence the participants' behavior in it. The division of labour constitutes the way in which the assigned goals and responsibilities are distributed among the participants in the system of activity. This system may change in order to respond to the changes that are caused by the new needs and the motives (Engeström, 1999).

The metacognitive contribution of the theory of activity in the framework of differentiated teaching

Activity theory does not involve only the process of learning through activities within the classroom. Learning is effective only when the students' conditions interact with the social changes and the social interaction that is applied in the classroom (Miettinen, 2003:87). Teachers therefore, mediate and re- adjust constantly not only the teaching process but also their own role taking nothing for granted because knowledge changes. Therefore, students are now more able to participate and to expand their knowledge (Koliadis, 2007).

At the same time, it is essential to develop the students' ability for social interaction and the peers' environment in order to establish a qualitative future coexistence (Gumpel \& Colan, 2000). As a result, in the framework of formal education and process of instruction, the designing and the adoption of effective teaching actions is required (Kress \& Elias, 2006). Students develop social skills through differentiated teaching that enables them to interact with each other and with the wider social environment (Hatzichristou, Lykitsakou, Lampropoulou \& Dimitropoulou, 2010).

On the other hand, activity theory allows teachers to pinpoint the level of individual knowledge of each student and the level of knowledge he or she can reach. In addition, the teacher supports and guides students and uses the appropriate tools, knowledge and methodology in order to teach effectively avoiding the use of just one method, encouraging innovation and alternative methods in achieving better teaching (Campell, et all, 2014). Activity theory combines various mediating methods with the existing knowledge and considers social factors, the issue of feedback, communication and self-evaluation. As such, learning is being considered as the product of an evolutionary process deeply rooted in the relations among the individual and social history (Vygotsky, 1978).

Activity theory is a socio cognitive theory which in order to be implemented awakens emotions, requires understanding and taking action. For this reason, Activity Theory in the framework of teaching socio - cognitive subjects plays an important role in the defining of the individual approach to knowledge, through collective activities and the expansion of existing knowledge. 
Differentiated instruction combined with activity theory offers students the opportunity to build upon prior knowledge while exploiting their own skills, interests, styles and talents. Teachers effectively take into consideration these aforementioned elements and create lessons that are interesting and meaningful for all students and lead to them toward academic success (Robinson et al., 2014). Campbell mentioned that teachers can differentiate methods, ways of setting queries to students in order to interact with the content and the questions that emerge their learning (Campbell, 2009:7).

\section{Implementation of activity theory in the framework of differentiated teaching: presentation through teaching}

The example that will be presented below aims at demonstrating the element of alternative teaching methods regarding students' way of-thinking and course of action. The teaching scenario was held in February 2017, in a Greek elementary school in Athens.

Class: $6^{\text {th }}$ grade of elementary school

Number of Students: Twenty (20) students in the experimental class where activity theory in the framework of differentiated teaching is being used.

Object of teaching-learning: "Learning about Salvador Dali's art"

Duration: 4 teaching hours

Basic terms of the teaching object: the artistic technique, the selection of the artist's displays and basic characteristics of Salvador Dali's art

Required knowledge and earlier perceptions or ideas of students: It is expected that students have some relative familiarity of related pictures in their textbooks, in museums, in videos, or in the media.

Target of teaching: Students should approach Dali's artistic technique

Other targets:

\section{Cognitive}

Students should be able to:

-realize the basic characteristics of Salvador Dali's art

-recognize the artist's paintings

\section{Emotional}

-Cultivate their aesthetic ability

Duration: 4 teaching hours 


\section{Technical infrastructure}

The desks should be assembled in such a way that favors students working in teams. The room should also possess a computer, an Internet connection, video wall, writing materials (pencils, pens, crayons, notebooks).

\section{Methodology}

The development scenario is based on activity theory and differentiated teaching which rooted in Vygotsky's original constructivism conceptualization and his descendants' sociocultural considerations, where special emphasis is placed on the learning process, the cognitive tools to mediate, the interaction between the groups involved and the socio-cultural environment where learning occurs (Robinson, Maldonado \& Whaley, 2014). Students, teachers, teaching tools, classroom environment, teaching modules, etc., are part of an interaction system. The same activity is the mediating tool and the unit of analysis of the learning process. At the first steps of the scenario and as the teacher is aware of his students' profile, interests and readiness, he/she gives them the choice to choose activities, namely various opportunities to choose either individually or in groups the learning object in order to find interest and to make them feel happy. Students are allowed to work individually or in teams. Furthermore, they are given questions in the form of a dialogue and objects will be shown to them, that support and implement the theory of activity. The teacher gives options based on student interest or learning style and this is a great motivator. In the framework of the particular theory, the activity is related to physical and psychological parameters. Human action is collective and includes cultural symbols, words and symbols which influence students' activities. The flexible grouping during the scenario, allows students to work in groups with peers whose learning abilities are different to them and all the students have the opportunity to work with peers who are dissimilar to learning styles, readiness, or interests. The teacher continually conducts assessments throughout the scenario. As the students are working in groups they are involved also in Independent study, a technique that is based on student's personal interest. The teacher is aware of what the students are capable to do in the skills that are required to complete into their group. The activities for each group are related to the students' readiness level and key skills that they need to acquire. The most common technique used in the presented scenario is to adjust discussion questions by the teacher according to the students' readiness or ability level. For that purpose, the teacher has prepared questions that are based on the student learning profile (Tomlinson, 2010). Specifically, the teacher uses Bloom's Taxonomy (Bloom et al, 1956) to develop queries from the very basic to the more advanced (Tomlinson, 2010). The presented example aims to make teaching interesting, through the active participation of all students, so that they can discover, explore, and eventually learn (discovery learning) themselves. Students work together in order to find the new knowledge and to discuss, analyze, express doubts, and engage in problem solving. 
First phase: Class preparation for teaching, introducing small groups of children

These groups consist of 4 students. Students are asked to answer questions posed by the teacher. Dialogue is encouraged based on the questions in order to achieve a better understanding of the particular subject of teaching.

The teacher gives images of three paintings of Salvador Dali (Face and Fruit Dish, The Persistence of Memory and Metamorphosis of Narcissus), which are a good introduction to what the students will be asked next. Students are given explanationsdirections for the process that will be followed and the teaching targets are set. Papers are distributed to all teams and each team receives specific guidance from the teacher.

\section{Second phase:}

In the framework of the theory of activity students that are set in groups state their opinions, their experience and their knowledge about the subject they represent, the so-called "expression of individual knowledge". Based on their own knowledge and experience students approach the "meaning" of each painting trying to understand, interpret and decode its essence. Then each group receives papers which include a series of questions in the form of a game and a leaflet with basic information about the life, art and the artistic technique of Salvador Dali. Students are divided into small equal teams and are shown in a video the following paintings by Salvador Dali. They observe the images that they see with the help of a computer and a video wall and look carefully at the details of the paintings shown. Where necessary they keep notes in their notebooks to use them in their group's assignments.

Each team undertakes a particular activity:

Group 1: This group is given a Salvador Dali-painting and they are asked to create a text, a poem or a song which depicts the students' emotions when observing and discussing the specific painting

Group 2: The second team creates images using play-dough that were shown in the painting they had to observe

Group 3: By searching in papers and on the Internet and viewing paintings by other artists that represent surrealism, the students in this group have to report on the similarities and the differences of other painters to Dali.

Group 4: In this group, students try to create a work of art influenced by the paintings of Salvador Dali and to give it their own name.

Group 5: Students are asked to make a collage from paintings of Salvador Dali and compose a text in which they include information about his life and the art of this great painter. 
While all groups are working on their assignments the teacher observes them, supports them and tries to guide their work.

\section{Third phase: Presentation of group work in class}

When the groups finish their projects they present the results of their assignmentsresearch-to the class, referring to any difficulties they have encountered, expressing their emotions and their overall experience. Next, the teacher initiates a discussion with all the groups about the art of Salvador Dali. Fhrough dialogues students exchange their opinions reaching the second step of differentiated theory in which "the individual knowledge contributes to the collective research". The assignments of each of the groups are displayed within the class.

\section{Fourth phase: Evaluation}

During evaluation whether the teaching targets were achieved is examined. Evaluation or assessment in the particular process is made by examining the notes that the teacher keeps regarding the participation of each member of the group, how well they collaborated with the others and the results of the team work. In addition, the display of the assignments in class is also another means of evaluation. A questionnaire based on the cognitive level, the participation and cooperation demonstrated by the students during the instructional scenario is given to each student. The questionnaire was structured with closed and open-ended questions and the level was graded. As for the participation, the cooperation of each student and the happiness achieved from the lesson there was a structured questionnaire given in the beginning, during and at the end of the lesson.

\section{Results}

The results of this teaching scenario concerning the implementation of "Activity Theory" during differentiated instruction in the educational process were compared, by graded difficulty worksheets and by a questionnaire, in order to check the participation and cooperation demonstrated in the lesson, with the results of previous graded difficulty worksheets and questionnaire. The previous students' evaluation was based on a different object of teaching-learning. Specifically, the lesson was titled "Learning about Picasso's art" and was carried out at the same class at the same school that had not received the implementation of "Activity Theory" during differentiated instruction.

Via this teaching example it was showed that "Activity Theory" during differentiated teaching effected the maximization of each student's academic achievements and potentials according to both their needs and interests, as well as to function as a stimulus for the dynamic forming of knowledge by the students themselves. Students after the lesson are well aware of the work of Salvador Dali and they can refer to the basic characteristics of his art. Furthermore, the way the students worked in nonhomogeneous teams involved positive results, as the students' communication 
prevails, collaborative effort was put toward common work and the acquisition of autonomy and self-activity of students was progressively achieved. Finally, the way of conducting the assessment emerged as a mean of feedback and positive confrontation of students' weaknesses and perceived as a strong motive for further effort.

\section{Conclusion}

The implementation of alternative activities demonstrates the special capabilities of the students and aims at improving the quality of the recently acquired knowledge. In the present research activity theory which, through the combination of individual approaches to learning and the collective approaches; achieves the transformation of the students' initial cognitive knowledge, was described. This approach can be implemented in the framework of differentiated theory using the students' profile, interests and talents in gaining new knowledge. The transition from standardized teaching to differentiated, from routine to flexibility and from passive guidance to individual thinking require the activation of new teaching methods that are based on individuality and the acquisition of knowledge. The theory of activity aims at changing people's socio cultural features of reality by constructing new ones, having as the ultimate goal the changing of people's natural and social reality.

\section{REFERENCES}

Anika B.A. (2012). Activity theory as a framework for investigating District- Classroom system interactions and their influences on technology integration. JRTE. Vol. 44. No. 4. Pp. 335-356.

Assor, A., Kaplan, H., \& Roth, G. (2002). Choice is good, but relevance is excellent: autonomyenhancing and suppressing teacher behaviors predicting students' engagement in schoolwork. British Journal of Educational Psychology, Vol. 72. Pp. 261-278. https://doi.org/10.1348/000709902158883

Bender, W.N. (2012). Differentiating instruction for students with learning disabilities: New best practices for general and special educators (3 rd Edition). Thousand Oaks, CA: Crowin

Bloom, B., Englehart, M. Furst, E., Hill, W., \& Krathwohl, D. (1956). Taxonomy of educational objectives: The classification of educational goals. Handbook I: Cognitive domain. New York, Toronto: Longmans, Green.

Campbell C., MacPherson S. Sawkins T (2014). «Preparing students for education, work and community: Activity theory in Task-based curriculum design». TESL Canada Journal. Vol. 31. No. 8. Pp. 68-92.

Campbell, B. (2009). To-with-by: A three-tiered model for differentiated instruction. New England Reading Association Journal, 44 (2), 7 -9.

Cha, H.J., \& Ahn, M. L. (2014). Development of design guidelines for tools to promote differentiated 
Instruction in classroom teaching. Asia Pacific Education Review, 15 (4), 511-523.

Chesley, G. M., \& Jordan, J. (2012). What's missing from teacher prep. Educational Leadership, 69 (8), 41-45.

Craib, I. (2011). Classical social theory, Translated by M. Tziantzi \& P. Lekka, Athens: Ellinika Grammata. . [In Greek]

Craib, I. (1998). Modern social theory (trans. Mary Tziantzi \& Leka Paraskevi). Athens: Ellinika Grammata. [In Greek]

Cranton, P. (2006). Understanding and promoting transformative learning. A Guide for educators of Adults (2ed). Higher and adult education series. San Francisco: Jossey-Bass.

Davydov V. (2003). The content and unsolved problem of activity theory in Perspectives on Activity Theory. Cambridge. UK. Cambridge University Press.

Dmitriev G. D. \& Stepanof S.S (1989). Lemma: "Creative Activity." Pedagogical Psychological Encyclopedia- Dictionary. Volume 3rd, Athens: Ellinika Grammata. Pp.1332 [in Greek]

Engeström Y. (2003) Innovative learning in work teams: Analyzing cycles of Knowledge creation in practice, in Perspectives on Activity Theory. Cambridge. UK. Cambridge University Press.

Engeström Y. (1987). Learning by expanding. An activity theoretical approach to developmental research. Helsinki: Orienta-Konsultit.

Fisher R. (2012). «Teaching writing: a situated dynamic». British Educational Research Journal. Vol. 38. No 2. Pp 299-317. https://doi.org/10.1080/01411926.2010.544711

Flouris, C. (2005). The architecture of the teaching and learning process. Athens: Gregoris Publications. [in Greek]

Hatzichristou, C., Lykitsakou, K., Lampropoulou, A., \& Dimitropoulou, P. (2010). Promoting the wellbeing of school communities: A systemic approach. In B. Doll, W. Pfohl, \& J. Yoon (Eds.), Handbook of youth prevention science, pp. 255-274. New York: Routledge.

Gamoran, A., \& Weinstein, M. (1995). Differentiation and opportunity in restructured schools. Madison, WI: Center on Organization and Restructuring of Schools. (ERIC Document No. ED 386 828).

Gumpel, T. P., \& Golan, H. (2000). «Teaching game-playing social skills using a self monitoring treatment package». Psychology in the Schools. Vol. 37. Pp. 253-261. https://doi.org/10.1002/(SICI)1520-6807(200005)37:3<253::AID-PITS5>3.0.CO;2-I

Hall, T. (2002). Differentiated instruction, Wakefield, MA: National Center on Accessing the General $\begin{array}{llll}\text { Curriculum, } & \text { Retrieved } 28 / 07 / 2012 & \text { from }\end{array}$ http://www.cast.org/publications/ncac/ncac diffinstruc.html

Joseph St., Thomas, M., Simonette, G. \& Ramsook, L., (2013). The Impact of Differentiated Instruction in a Teacher Education Setting: Successes and Challenges. International Journal of Higher Education, 2 (3). 
Kim, J. (2005). The effects of a Constructivist Teaching Approach on Student Academic Achievement, Self-concept and Learning Strategies, Asia Pacific Education Review,6, (1), 7-19

Koliadis E. (2007). Learning Theories and Educational Practice Volume III. Athens: Gregoris. [in Greek] Kossivaki, F. (2003). Alternative Teaching. Proposals for transition from the teaching of the object to the teaching of the active subject. Athens: Gutenberg. [in Greek]

Koutselini, M. \& Patsalidou, Fr., (2015). Engaging School Teachers and School Principals in an Action Research in Service development as a means of pedagogical self-awareness. Educational Action Research., 23(2):124-140

Koutselini-loannidou, M. \& Pyrgiotakis, I.E (2015). Differentiation of teaching and learning. Athens: Pedio. [in Greek]

Koutselini, M. (2006). Differentiating Teaching - Learning in mixed Ability classes: Philosophy and application. Book A. Nicosia. [In Greek]

Koutselini, M. \& Persianis, P. (2001). «Theory - practice divide in teacher education and the role of the traditional values». Teaching in Higher Education. Vol. 5. No 4. Pp. 37- 49.

Kress, J. S., \& Elias, M. J. (2006). "School based social and emotional learning programs». In Renninger, K. \& Sigel, I. (Eds.): Handbook of child psychology: Vol.4. Child psychology in practice (6th ed., pp. 592-618). Hoboken, NJ: John Wiley and Sons.

Leont'ev A.N. (1978) Activity consciousness and personality. Englewood Cliffs, N J, Prentice Hall.

Matsagouras, H. (1998). Organization and management of the classroom. Athens: Gregoris. [in Greek]

Matsagouras I.G. (1998). Theory and Practice of Teaching, Volume B, Teaching strategies, critical thinking in teaching practice. Athens: Gutenberg. [in $\mathrm{Gr}$

McCombs, B. (2003). «A framework for the redesign of K-12 education in the context of current educational reform». Theory into Practice. Vol. 42. No 2. Pp. 93-101. https://doi.org/10.1207/s15430421tip4202_2

Miettinen R. (2003). Transcending traditional school learning: Teacher's work and networks of learning in Perspectives on Activity Theory. Cambridge. UK. Cambridge University Press.

Morgan, H. (2014). Maximizing Student Success with Differentiated Learning. The Clearing House: A Journal of Educational Strategies, Issues and Ideas, 87 (1), 34-37. https://doi.org/10.1080/00098655.2013.832130

Panteliadiou, S. \& Filippatou, D. (2013). Differentiated Teaching Theoretical approaches and educational practices. Athens: Pedio. [in Greek]

Park, Y. (2015). «Understanding Synchronous Computer-Mediated Classroom discussion through Cultural Historical Activity Theory». TOJET. Vol. 14. No 2. Pp 219-228.

Piaget, J. (1964). «Cognitive development in children. Development and learning». Journal of research in science teaching. Vol. 2. No 3. Pp. 176-186. 
Reis M.S., McCoach D. B, Little, A.C., Lisa M. Mulle M.L. \& Kaniskan R.B., (2011).The Effects of Differentiated Instruction and Enrichment Pedagogy on Reading Achievement in Five Elementary Schools. American Educational Research Journal. 48 (2) 462-501. https://doi.org/10.3102/0002831210382891

Robinson L., Maldonado N. \& Whaley J., (2014). 'Perceptions about Implementation of Differentiated Instruction', Paper presented at the Annual Mid-South Educational Research (MSERA) conference Knoxville, Tennessee: November 7, 2014

Santangelo, T., \& Tomlinson, C. (2009). The application of differentiated instruction in post-secondary environments: Benefits, challenges, and future directions. International Journal of Teaching and CLearning in Higher Education, 20 (3), 307-323.

Stetsenko A. (2008). «From relational ontology to transformative activist stance on development and learning: Expanding Vygotsky's (CHAT) project». Cultural Studies of Science Education. Vol. 3. Pp. 471-491. https://doi.org/10.1007/s11422-008-9111-3

Taylor A. (2014). «Community service-learning and cultural-historical activity theory». Canadian Journal of Higher Education. Vol. 44. No 1. Pp. 9-107.

Theophilidis, Ch. (2009). Cracks in the iceberg of traditional teaching. Athens: Gregoris. [in Greek]

Tomlinson, C. A. (2014). The Differentiated Classroom: Responding to Needs of all learners, 2nd Edition.

Tomlinson, C. (2010). Differentiation of work in the Classroom. (trans. Chris Theophilidis \& Despina Martidou-Forsie), Athens: Editions Gregoris. [in Greek]

Tomlinson, C. A., (2009) Intersections between differentiation and literacy instruction: Shared principles worth sharing. The NERA Journal, 45 (1), 28-33. Retrieved from Education Research Complete database.

Tomlinson, C. (2005). "Grading and differentiation: Paradox or good practice? ». Theory into Practice. Vol. 44. No. 3. Pp.262-269. https://doi.org/10.1207/s15430421tip4403_11

Triscari, J. \& Swartz, A. (2007). «Transformation Through Collaboration». In Cranton, P. \& Taylor, E. (Eds.): $7^{\text {th }}$ International transformative learning conference Transformative Learning: Issues of Difference and Diversity (pp. 316-320). Albuquerque, New Mexico.

Valiandes, S. \& Neophytou, L., (2017). Differentiated teaching. Functional and effective implementation. Athens: Pedio. [in Greek]

Valiandes, S. and Koutselini, M. (2008). Application of differentiation of teaching in classes of mixed abilities: Conditions and subjects to discussion. Available in: http//diaforopiisi.net/arthra/Diaforopiisi_proupotheseis_themata_pros_syzitisi_paid_etai_2008pdf [in Greek].

Vygotsky, L. (1978). Mind in society: The development of higher psychological processes. Harvard: Harvard University Press. 
Zhang J (2014) «Activity Theory as a framework for designing the model of college English listening». International Education Studies. Vol. 7. No. 5. Pp 49-54. 